STUDI

FRANCESI

\section{Studi Francesi}

Rivista quadrimestrale fondata da Franco Simone

160 (LIV | I) | 2010

II simbolismo. Nomi, aspetti, momenti. Studi in memoria di Ivos Margoni

\title{
Pierre Glaudes, Esthétique de Barbey d'Aurevilly
}

\section{Ida Merello}

\section{OpenEdition}

Journals

Edizione digitale

URL: http://journals.openedition.org/studifrancesi/7314

DOI: 10.4000/studifrancesi.7314

ISSN: 2421-5856

\section{Editore}

Rosenberg \& Sellier

\section{Edizione cartacea}

Data di pubblicazione: 1 avril 2010

Paginazione: 176-177

ISSN: 0039-2944

\section{Notizia bibliografica digitale}

Ida Merello, «Pierre Glaudes, Esthétique de Barbey d'Aurevilly», Studi Francesi [Online], 160 (LIV | I) | 2010, online dal 30 novembre 2015, consultato il 09 janvier 2021. URL: http://journals.openedition.org/ studifrancesi/7314; DOI: https://doi.org/10.4000/studifrancesi.7314

Questo documento è stato generato automaticamente il 9 janvier 2021.

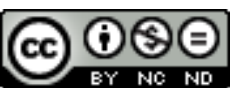

Studi Francesi è distribuita con Licenza Creative Commons Attribuzione - Non commerciale - Non opere derivate 4.0 Internazionale. 
Pierre Glaudes, Esthétique de Barbey d'Aurevilly

Ida Merello 


\section{NOTIZIA}

PIERRE GLAUDES, Esthétique de Barbey d'Aurevilly, Paris, Garnier, 2009, pp. 196.

1 Il volume è costituito da una raccolta di articoli, di cui molti di recentissima pubblicazione (2008). L'A. pone innanzitutto il problema della focalizzazione di Barbey, la cui opera non può venir letta alla luce delle consapevolezze successive dovute ai lavori di Freud, Derrida o Lacan, ma neppure può rimanere imprigionata in una corrente clerical-reazionaria che non aiuta a far luce sugli elementi visionari dello scrittore. Ritiene peraltro imprescindibile il rapporto con Joseph de Maistre, non solo per il dogmatismo religioso e la concezione del peccato originale che autorizzavano un pensiero contrario all'ideologia della ragione e del progresso, ma anche per l'eleganza di uno stile e un'estetica dell'intensità che ugualmente Barbey condivide. L'A. approfondisce il confronto con gli scrittori realisti, mostrando le diverse modalità estetiche dello scrittore, determinate da una diversa visione della realtà, sempre immersa nella trascendenza, fino alla produzione di un fantastico soprannaturale. Se uno dei modelli di scrittura più importanti rimane Walter Scott, l'A. intravede anche nella concezione del grottesco di Barbey elementi donchisciotteschi, ben evidenti nel Chevalier des Touches, e accresciuti da un'accentuazione dei caratteri di nobiltà d'animo. In conclusione l'A. traccia il ritratto di uno scrittore dandy, ispirato dal romanzo storico e realista, determinato dal ritorno ai valori religiosi del Romanticismo e dalla sua propria conversione, senza accenti di rivolta, ma con una spiccata vocazione alla trascendenza e alla tensione verso il sublime (preferibilmente della sofferenza), che viene accostato al suo inverso diabolico, una zona oscura dell'animo umano, espressione del male della modernità. 